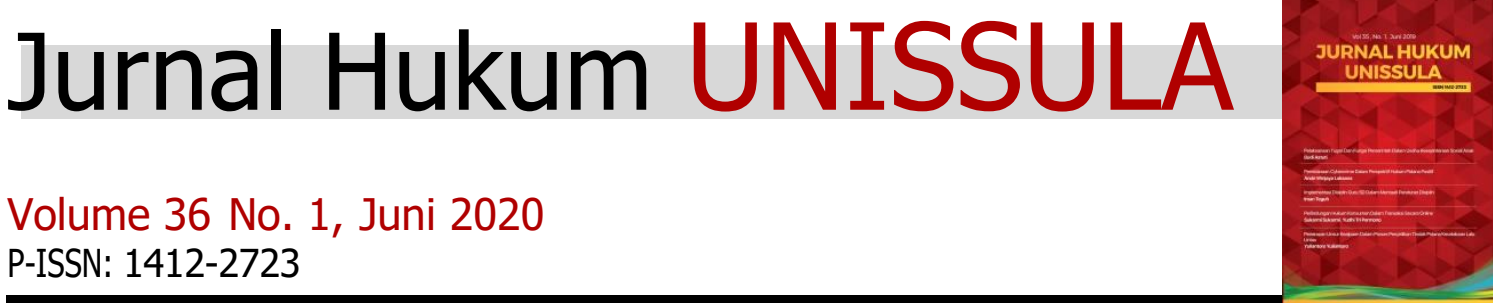

This work is licensed under a Creative Commons Attribution 3.0 International Licens

\section{ANCAMAN PIDANA MATI TERHADAP PEMBERANTASAN TINDAK PIDANA KORUPSI}

\author{
Abdul Manan \\ Faculty of Law, Sultan Agung Islamic University, Indonesia. E-mail: manan.abdul11@gmail.com
}

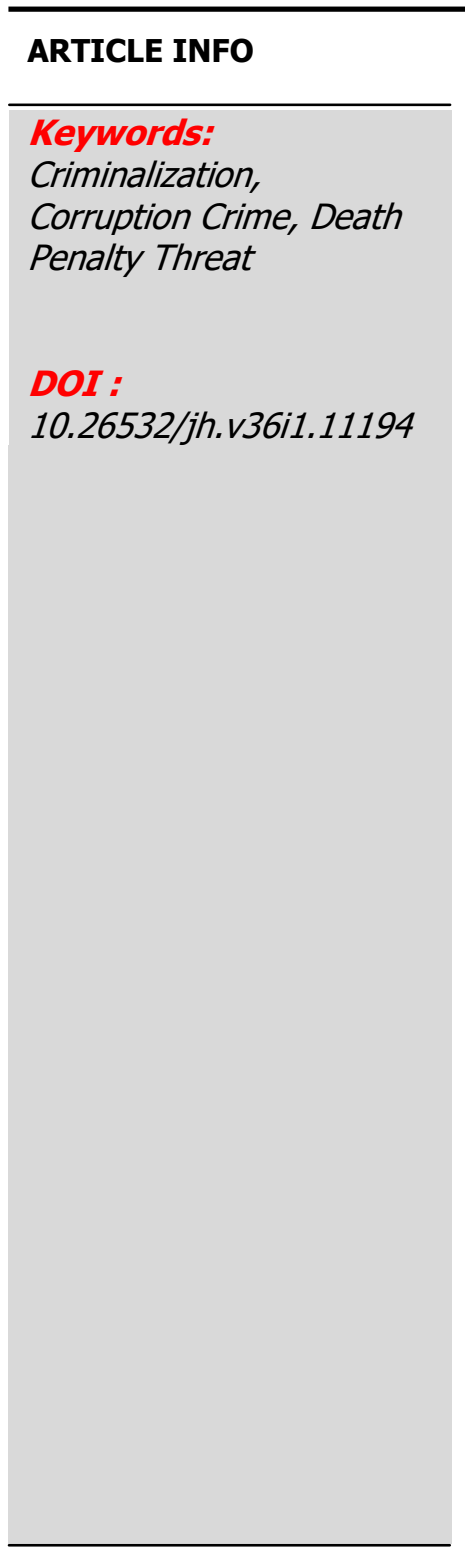

\section{ABSTRACT}

This research aims to determine the policy on the formulation of the death penalty against the eradication of corruption and to find out the obstacles and solutions in implementing the death penalty against the eradication of corruption based on the applicable laws in Indonesia. This research method uses an empirical juridical approach. Based on the research findings, it is known that the capital punishment policy can be interpreted as a special maximum criminal sanction in which the level of implementation in Indonesia is difficult to apply because so far capital punishment still reaps pros and cons in its imposition in various criminal cases. no exception in the criminal case of corruption. There are several weaknesses and obstacles in the application of the death penalty in the eradication of the criminal act of corruption, one of which is the death penalty as a burden is only punishable for certain criminal acts of corruption and is not aimed at all forms of corruption. In certain circumstances the most likely juridical reason to occur is in the form of a recidive crime, however it does not contain any rules or definitions (recidive) even though repetition is a juridical technical term.

Penelitian ini bertujuan untuk mengetahui kebijakan perumusan hukuman mati terhadap pemberantasan korupsi serta untuk mengetahui kendala dan solusi dalam penerapan pidana mati terhadap pemberantasan korupsi berdasarkan hukum yang berlaku di Indonesia. Metode penelitian ini menggunakan pendekatan yuridis empiris. Berdasarkan temuan penelitian diketahui bahwa kebijakan pidana mati dapat diartikan sebagai sanksi pidana maksimum khusus yang tingkat penerapannya di Indonesia sulit diterapkan karena selama ini pidana mati masih menuai pro dan kontra dalam penerapannya di berbagai bidang. kasus-kasus kriminal. tak terkecuali dalam kasus pidana korupsi. Terdapat beberapa kelemahan dan kendala dalam penerapan pidana mati dalam pemberantasan tindak pidana korupsi, salah satunya pidana mati sebagai beban yang hanya dapat dijatuhkan pada tindak pidana korupsi tertentu dan tidak ditujukan pada semua bentuk tindak pidana korupsi. korupsi. Dalam keadaan tertentu alasan yuridis yang paling mungkin terjadi adalah dalam bentuk tindak pidana residif, namun tidak memuat aturan atau definisi (residif) meskipun pengulangan merupakan istilah teknis yuridis.

Copyright @ 2020 JURNAL HUKUM UNISSULA. All rights reserved. 


\section{A. PENDAHULUAN}

Hukum dimaknai menetapkan apa yang harus dilakukan dan atau apa yang boleh dilakukan serta yang dilarang. Sasaran hukum yang hendak dicapai tidak hanya seseorang yang dianggap telah melawan hukum, akan tetapi juga perbuatan hukum yang mungkin akan terjadi, dan kepada alat perlengkapan negara untuk be rtindak sesuai dengan hukum. ${ }^{1}$ Proses pembangunan dapat menimbulkan kemajuan dalam kehidupan masyarakat, selain itu dapat juga mengakibatkan perubahan kondisi sosial masyarakat yang memiliki dampak sosial sosial negatif, terutama menyangkut masalah peningkatan tindak pidana yang meresahkan masyarakat. Salah satunya adalah masalah korupsi.

Maraknya korupsi di Indonesia disinyalir terjadi di semua bidang dan sektor pembangunan. Apalagi setelah ditetapkannya pelaksanaan otonomi daerah berdasarkan Undang-Undang No. 22 Tahun 1999 jo UndangUndang No. 32 Tahun 2004 jo. Undang-Undang No. 12 Tahun 2008 tentang Pemerintahan Daerah, disinyalir korupsi tidak hanya pada tingkat Pemerintah Pusat tetapi juga pada tingkat Pemerintah Daerah dan bahkan merambah pada tingkat Pemerintah Desa. dan yang lebih memprihatinkan lagi korupsi tidak saja terjadi pada lingkungan pemerintahan saja melainkan juga merambah sampai lembaga perwakilan rakyat, lembaga peradilan, lembaga pendidikan dan swasta. ${ }^{2}$

Korupsi merupakan salah satu tindak pidana yang mempunyai dampak atau akibat yang sangat buruk bagi perkembangan suatu bangsa. Dampak yang ditimbulkan dapat menyentuh berbagai bidang kehidupan yang dapat membahayakan stabilitas dan keamanan masyarakat, membahayakan pembangunan sosial ekonomi,dan juga politik, serta dapat merusak tatanan nilai-nilai demokrasi dan moralitas karena lambat laun perbuatan ini menjadi sebuah budaya yang juga akan menghambat cita-cita menuju sebuah bangsa yang makmur dan sejahtera. ${ }^{3}$

Realitas ini menunjukkan bahwa penegakan hukum di Indonesia masih saja menghadapi kendala berkaitan dengan aspek yuridis terlebih dari segi pengaturan sanksi yang sampai saat ini belum dapat membuat para elit birokrat jera terhadap aksi korupsi. ${ }^{4}$ Beberapa kasus besar yang mencerminkan lemahnya penegakan hukum di Indonesia seperti Kasus suap cek pelawat terhadap beberapa anggota DPR periode 1999-2004, dalam pemilihan DGS BI. Oleh KPK, Miranda hanya dikenakan Pasal 5 dan Pasal 13 Undang-Undang tentang Pemberantasan Tindak Pidana Korupsi jo. Pasal 55 Ayat 1 dan 2 atau Pasal 56 KUHP, dengan dugaan membantu dan turut serta dalam perbuatan korupsi atas tersangka lain, Nunun Nurbaeti,

1 AA Parimita, Gede Khrisna Putra, Edward Thomas Lamury, Wewenang Komisi Pemberantasan Korupsi Dalam Penyadapan Untuk Mengungkap Kasus Tindak Pidana Korupsi, Kertha Negara: Jurnal Ilmu Hukum, Volume 7 Nomor 8 2019, hlm. 3

2 Lembaga Administrasi Negara Republik Indonesia, Pemberatan Korupsi, Modul Pilot Project Pendidikan dan Pelatihan Pra Jabatan, Tahun 2009, hlm. 15.

3 Op. Cit, AA. Parimita, hlm. $5 .$.

4 Jeremy Pope, Strategi Memberantas Korupsi, Elemen Sistem Integrasi Nasional, Edisi I, Yayasan Obor Indonesia, Jakarta, 2003, hIm, 30. 
dalam pengaliran cek pelawat ke anggota DPR $1999-2004 .^{5}$ Belum lagi baru-baru ini muncul kasus yang mencengangkan masyarakat Indonesia, seperti pernyataan yang disampaikan Menteri Dalam Negeri (Mendagri) seusai pelantikan Wakil Gubernur Bengkulu, yang menyatakan sebanyak 297 atau sekitar 86,2\% dari jumlah 524 Kepala Daerah yang terdiri Gubernur, Bupati dan Wali Kota di negeri ini terjerat kasus korupsi dan sudah berstatus tersangka, terdakwa bahkan terpidana. Hal ini tentunya sangat disayangkan ketika para Pejabat Daerah yang seharusnya menjaga amanah yang dipercayakan kepadanya untuk membangun daerahnya dan mensejahteraan masyarakat, akan tetapi justru berbalik dengan memperkaya dirinya sendiri.

Melihat fenomena kasus korupsi yang terjadi di negeri ini tampaknya para penggiat anti korupsi terutama para penegak hukum masih setengah hati sehingga tidak berjalan secara maksimal karena penegak hukum dipermainkan pihak-pihak yang berkepentingan seperti Kepolisian, Kejaksaan, Pengacara, hingga pelaku korupsi. Komisi Pemberantasan Korupsi atau yang akrab disebut KPK juga terkesan sangat hati-hati dan kurang tegas di dalam mengambil sikap atau langkah hukum sehingga seperti kita tahu masih banyak para pelaku koruptor masih bebas berkeliaran. Hasilnya, korupsi bukan menurun, akan tetapi justru makin tumbuh subur di negeri ini. ${ }^{6}$

Berdasarkan latar belakang di atas, maka penelitian ini memiliki tujuan untuk mengetahu mengenai pengertian pidana mati dan tindak pidana korupsi serta kebijakan formulasi ancaman pidana mati dalam Undang-Undang No. 31 Tahun 1999 jo. Undang-Undang No. 20 Tahun 2001 tentang Pemberantasan Tindak Pidana Korupsi berikut dengan kendala dan solusi dalam implementasinya.

\section{B. METODE PENELITIAN}

Penelitian ini menggunakan pendekatan yuridis empiris, yaitu suatu cara yang digunakan untuk memecahkan masalah dengan terlebih dahulu meneliti data primer di lapangan kemudian dilanjutkan dengan penelitian terhadap data-data sekunder yang ada. Penelitian ini akan menghasilkan data deskriptif berupa data-data tertulisatau lisan dari obyek penelitian secara holistic (utuh), yang berkaitan dengan Tinjauan Yuridis terhadap Ancaman Pidana Mati Terhadap Pemberantasan Tindak Pidana Korupsi di Indonesia. ${ }^{7}$

\section{HASIL PENELITIAN DAN PEMBAHASAN 1. Pidana Mati dan Tindak Pidana Korupsi a. Pidana Mati}

5 Ibid. hlm. 31

6 A. Ahsin Thohari, (Bukan) Menggantang Asap Pemberantasan Korupsi Di Indonesia, Jurnal Legislasi Indonesia, Volume 8 No. 2, 2011, hlm. 340-341

7 Mustaghfirin dan Irwanto Efendi, Tinjauan Yuridis Terhadap Implementasi Pidana Korupsi Dalam Upaya Mengembalikan Kerugian Keuangan Negara, Jurnal Pembaharuan Hukum, Volume 2 No. 1 2015, hlm. 14 
Pidana dalam hukum pidana yaitu suatu alat dan bukan tujuan dari hukum pidana, yang apabila dilaksanakan tiada lain ialah berupa penderitaan atau rasa tidak enak bagi yang bersangkutan disebut terpidana. Tujuan utama hukum pidana adalah ketertiban, yang secara khusus dapat disebut terhindarnya masyarakat dari perkosaanperkosaan terhadap kepentingan hukum yang dilindungi. ${ }^{8}$

Menurut Johanes Andenaes, tujuan utama dari pidana adalah untuk memuaskan tuntutan keadilan (to satisfy the claims of justice). Sedangkan pengaruh-pengaruh lainnya menguntungkan ialah hal sekunder, jadi menurutnya bahwa pidana yang dijatuhkan sematamata untuk mencari keadilan dengan melakukan pembalasan. ${ }^{9}$ Senada dengan Johanes Andenaes, Immanuel Kant, mentakan bahwa pidana menghendaki agar setiap perbuatan melawan hukum harus dibalas karena merupakan suatu keharusan yang bersifat mutlak yang dibenarkan sebagai pembalasan. Oleh karena itu, konsekuensinya ialah setiap pengecualian dalam pemidanaan bertujuan untuk mencapai tujuan tertentu selain pembalasan harus dikesampingkan. Penganut ajaran teori ini adalah Hegel, berpendapat bahwa pidana merupakan suatu keharusan logis sebagai konsekuensi dari adanya kejahatan. Kejahatan adalah pengingkaran terhadap ketertiban hukum suatu negara yang merupakan perwujudan dari cita-cita susila, maka pidana merupakan suatu pembalasan.

Lebih lanjut Hegel mengatakan bahwa tindak pidana itu harus ditiadakan dengan melakukan pemidanaan sebagai suatu pembalasan yang seimbang dengan beratnya perbuatan yang dilakukan. Kemudian tokoh lainnya, yaitu Hugo De Groot dengan mengikuti pendapat dari Phitagoras, menuliskan bahwa kita tidak seharusnya menjatuhkan suatu pidana karena seseorang telah melakukan kejahatan, akan tetapi untuk mencegah supaya orang jangan melakukan kejahatan lagi. ${ }^{10}$ Sementara itu, Pidana mati adalah pidana yang terberat. Karena pidana ini berupa pidana yang terberat, yang pelaksanaannya berupa penyerangan tehadap hak hidup bagi manusia yang sesungguhnya hak ini hanya berada ditangan Tuhan, maka tidak heran sejak dulu sampai sekarang menimbulkan pendapat pro dan kontra, bergantung dari kepentingan dan cara memandang pidana mati tu sendiri. ${ }^{11}$

Menurut J.E Sahetapy, pidana mati ialah suatu permasalahan yang sangat mendasar dan seyogianya jangan dikaitkan dengan jenis kejahatan yang dilakukan oleh si pelaku. Sekali dikaitkan pidana mati berdasarkan apakah perbuatan itu sangat kejam, kurang, atau tidak sadis, kurang atau tidak berperikemanusiaan, kurang atau tidak dan sebagainya. ${ }^{12}$

8 Op.Cit,Mustaghfirin, hlm. 14

9 Sutochid Kartanegara, Hukum Pidana Bagian Satu, Balai Lektur Mahasiswa, Jakarta, 1999, hlm. 56.

10 Djoko Prakoso, Hukum Penitensir Di Indonesia, Armico, Bandung, 1988, hlm. 20

11 Op. Cit,Mustaghfirin, hlm. 16

12 Muladi, Lembaga Pidana Bersyarat, Alumni, Bandung, 1992, hlm. 25 
Menyadari akan eksistensi pidana mati sebagai pidana yang mempunyai sifat yang demikian, maka di Negeri Belanda sendiri tempat asalnya KUHP sejak tahun 1870 tidak lagi mengenal pidana mati, sebab pidana mati telah dihapuskan dari W.v.S.nya, kecuali dipertahankannya dalam Hukum Pidana Militer. Sesungguhnya pembentuk KUHP sendiri telah memberikan suatu isyarat bahwa pidana mati tidak dengan mudah dijatuhkan, menggunakan upaya pidana mati harus dengan sangat hati-hati, tidak boleh gegabah. Isyarat itu adalah bahwa, bagi setiap kejahatan yang diancam dengan pidana mati, selalu diancamkan juga pidana alternatifnya, ialah pidana penjara seumur hidup atau pidana penjara sementara waktu setinggitingginya 20 tahun. Misalnya Pasal 365 ayat (4), Pasal 340, Pasal 104 dan lain-lain. ${ }^{13}$

Alasan yang membolehkan pidana mati, beranggapan bahwa pidana mati bukanlah sarana utama untuk mengatur, menertibkan dan memperbaiki masyarakat. Pidana mati hanya merupakan sarana terakhir apabila sarana lain tidak berfungsi dengan baik. Oleh karena itu pidana mati masih dianggap dapat diterapkan dalam KUHP karena masih relevan dan tidak bertentangan dengan Undang-Undang Dasar Negara Republik Indonesia Tahun 1945. Jadi, Hak Asasi Manusia (HAM) dapat dibatasi dan diperkuat dengan penempatan Pasal 28J sebagai pasal penutup dari seluruh ketentuan yang mengatur tentang HAM dalam bab XA UUDNRI Tahun 1945 sehingga secara penafsiran sistematis HAM yang diatur dalam Pasal 28A sampai dengan Pasal 28I tunduk pada pembatasan hak asasi manusia yang diatur dalam Pasal 28] UUDNRI Tahun $1945 .^{14}$

Pada dasarnya ditetapkannya pidana mati dengan tujuan sebagai salah satu sarana untuk menanggulangi kejahatan hakikatnya merupakan suatu pilihan kebijakan. Akan tetapi, dalam menetapkan suatu kebijakn bisa saja orang berpendapat pro dan kontra terhadap pidana mati. Apabila suatu kebijakan sudah diambil atau diputuskan dan kemudian dirumuskan (direformulasikan) dalam suatu UndangUndang, maka dilihat dari sudut kebijakan atau politik hukum pidana (penal policy) dan kebijakan kriminal (criminal policy), kebijakan formulasi pidana mati itu tentunya diharapkan dapat diterapkan pada tahap aplikasiya. ${ }^{15}$

\section{b. Tindak Pidana Korupsi}

Istilah korupsi berasal dari satu kata dalam bahasa latin yakni corupptio atau corruptus yang disalin dalam bahasa Inggris menjadi corruption atau corrupt, dalam bahasa Perancis menjadi corruption

13 Martiman Prodjohamidjojo, Memahami Dasar-Dasar Hukum Pidana Indonesia, Pradnya Paramita, Jakarta, 1995, hlm. 127

14 Winastiti Yuliana Sekarpuri, Implementasi Purusan Pidana Mati Oleh Kejaksaan Negeri Surakarta Dalam Perkara Pembunuhan Berencana, Sebelas Maret, Surakarta, 2009, hlm. 49

15 Krisnanda Etika Putri, Eko Soponyono, R.B. Sularto, Rekonstruksi Kebijakan Hukum Pidana Terhadap Eksekusi Pidana Mati, Diponegoro Law Journal, Volume 5 No. 3, 2016, hlm. 5-7 
dan dalam bahasa Belanda disalin menjadi corruptive (korruptie). ${ }^{16}$ Korupsi secara harfiah dimaknai kebusukan, keburukan, kebejatan, ketidakjujuran, dapat disuap, tidak bermoral, penyimpangan dari kesucian, kata-kata atau ucapan yang menghina atau menfitnah. Andi Hamzah dalam kamus hukumnya mengartikan korupsi sebagai suatu perbuatan buruk, busuk, bejat, suka disuap, perbuatan yang menghina atau menfitnah, menyimpang dari kesucian, tidak bermoral. ${ }^{17}$

Kartini Kartono mengatakan, bahwa korupsi adalah tingkah laku individu yang menggunakan wewenang dan jabatan guna mengeruk keuntungan pribadi, merugikan kepentingan umm dan negara. ${ }^{18}$ Jadi, korupsi merupakan gejala salah pakai dan salah urus dari kekuasaan demi keuntungan pribadi, salah urus terhadap sumber-sumber kekayaan negara dengan menggunakan wewenang dan kekuatankekuatan formal misalnya dengan alasan hukum dan kekuatan senjata untuk memperkaya diri sendiri. ${ }^{19}$

Menurut Baharuddin Lopa, corruption ialah the offering and accepting of bribes (penawaran/pemberian dan penerimaan haadiahhadiah berupa suap). Di samping itu duartikan juga "decay" yaitu kebusukan atau kerusakan. Yang busuk atau rusak ialah moral akhlak oknum yang melakukan perbuatan korupsi sesuai arti corruptus atau corruption moral perversion (kerusakan moral). ${ }^{20}$

Korupsi dalam Pasal 2 Undang-Undang No. 31 Tahan 1999 jo. Undang-Undang No. 21 Tahun 2001 tentang Pemberantasan Tindak Pidana Korupsi, berbunyi sebagai berikut ${ }^{21}$ :

1) Setiap orang yang secara melawan hukum melakukan perbuatan memperkaya diri sendiri atau suatu koorporasi yang dapat merugikan negara atau perekonomian negara;

2) Setiap orang lain atau dengan tujuan untuk menguntungkan diri sendiri atau suatu kooporasi menyalahgunakan kewenangan, kesempatan atau sarana yang ada padanya karena jabatan atau kedudukan yang dapat merugikan keuangan negara atau perekonomian negara.

Tindak pidana korupsi KUHP adalah kejahatan atau kesalahan ataupun perbuatan-perbuatan yang bisa dikenal tindak dan sanks hukum. Dalam Pasal 419 KUHP disebutkan bahwa ${ }^{22}$ :

16 Adami Chazawi, Hukum Pidana Materiil dan Formil Korupsi di Indonesia, Cet Ke-2, Bayu Media, Malang, 2005, hlm. 1

17 Andi Hamzah, Pemberantasan Korupsi Melalui Hukum Nasional dan International, Ghalia Indonesia, Jakarta, 1986, hlm. 339

18 Mahardika, Firman Wijaya, Kajian Yuridis Fungsi Pencegahan Komisi Pemberantasan Korupsi Dalam Pemberantasan Tindak Pidana Korupsi Pengadaan Barang Dan Jasa Secara Elektronik Di Provinsi Dki Jakarta, Jurnal Hukum Adigama, Volume 1 No. 2, Januari 2018, hlm. 3

19 Martiman Prodjohamidjojo, Menerapkan Pembuktian Terbalik Dalam Delik Korupsi (UU No. 31 Tahun 1999), Mandar Maju, Bandung, 2001, hlm. 9

20 Baharuddin Lopa, Masalah Korupsi Dan Pemecahannya, Kipas Putih, Jakarta, 1997, hlm. 1

21 Pasal 2 Undang-Undang No. 31 Tahan 1999 jo. Undang-Undang No. 21 Tahun 2001 tentang Pemberantasan Tindak Pidana Korupsi 
1) Yang menerima hadiah atau perjanjian itu diberikan kepadanya untuk membujuknya supaya ia menjalankan atau mengalpakan sesuatu dalam jabatannya, berlawanan dengan kewajibannya;

2) Yang menerima hadiah, sedang ia tahu bahwa hadiah itu diberikan kepadanya berhubungan ia telah menjalankan atau mengalpakan suatu perbuatan dalam jabatannya berlawanan dengan kewajibannya.

Jika ditinjau dari instrumen hukumnya, sebenarnya Indonesia memiliki banyak peraturan perundang-undangan yang mengatur pemberantasan tindak pidana korupsi. Di antara peraturan itu adalah KUHP, Undang-Undang No. 31 Tahun 1999 tentang Pemberantasan Tindak Pidana Korupsi beserta revisinya melalui Undang-Undang 20 Tahun 2001, bahkan juga diperkuat dengan adanya Komisi Pemberantasan Korupsi (KPK) yang dibentuk beradasarkan UndangUndang No. 32 Tahun 2002. ${ }^{23}$

\section{Kebijakan Formulasi Ancaman Pidana Mati Dalam Undang- Undang No. 31 Tahun 1999 jo. Undang-Undang No. 20 Tahun 2001 tentang Pemberantasan Tindak Pidana Korupsi}

Undang-Undang No. 31 Tahun 1999 jo. Undang-Undang No. 20

Tahun 2001 tentang Pemberantasan Tindak Pidana Korupsi, merupakan produk hukum sebagai hasil dari kebijakan pemerintah yang bertujuan untuk penanggulangan terhadap kejahatan korupsi di Indonesia. ${ }^{24}$ Kebijakan ini dilakukan mengingat ketentuan-ketentuan tindak pidana korupsi yang terdapat dalam KUHP dirasa kurang efektif dalam mengantisipasi atau bahkan mengatasi permaslahan tindak pidana korupsi ketika pada masa orde baru waktu itu. Oleh karena itu, dibentuklah suatu peraturan perundang-undangan guna memberantas masalah korupsi, dengan harapan dapat mengisis serta menyempurnakan kekurangan yang terdapat pada KUHP. Dengan berlakunya Undang-Undang No.20 Tahun 2001 tentang Perubahan atas Undang-Undang No. 31 Tahun 1991 tentang Pemberantasan tindak Pidana korupsi, maka ketentuan Pasal 209 KUHP, Pasal 210 KUHP, Pasal 387 KUHP, Pasal 388 KUHP, Pasal 415, Pasal 416 KUHP, Pasal 417 KUHP, Pasal 418 KUHP, Pasal 419 KUHP, Pasal 420 KUHP, Pasal 423 KUHP, Pasal 425 KUHP, Pasal 434 KUHP dinyatakan tidak berlaku. ${ }^{25}$

Menurut Achmad Ali bahwa pidana mati terhadap pelaku kejahatan korupsi sangat dibutuhkan dengan melihat konteks negara hari ini, tapi hal ini dilakukan dengan selektif dan dimulai dari koruptor kelas

22 Pasal 419 Ktab Undang-Undang Hukum Pidana

23 Dwi Lapriesta R, Nyoman A. Martana, Analisis Terhadap Kebijakan Pemerintah Dalam Pemberantasan Korupsi Sebagai Upaya Menciptakan Pemerintahan Yang Bersih(Clean Governance), Jurnal Kertha Negara, Volume 4 No. 2, Februari 2016, hlm. 3-4

24 Moch Choirul Rizal, Kebijakan Hukum Tentang Bantuan Hukum Untuk Pemberantasan Korupsi Di Indonesia, Al-Jinayah: Jurnal Hukum Pidana Islam, Volume 4 No. 1, Juni 2018, hlm. 153

25 Darwan Prinst, Pemberantasan Tindak Pidana Korupsi, Bandung, 2002, hal. 31 
kakap. Pidana mati ini bukan sebagai pembalasan dendam tetapi berfungsi untuk menakut-nakuti agar warga masyarakat lain tidak ikutikut melakukan korupsi. ${ }^{26}$

Terdapat beberapa alasan mengenai pentingnya penjatuhan pidana mati tersebut untuk diberlakukan terhadap korupsi setidaknya dapat disarikan dari beberapa pandangan sebagai berikut ${ }^{27}$ :

a. Penjatuhan pidana mati terhadap tindak pidana korupsi didasarkan pada ide "menghindari tuntutan/reaksi masyarakat yang bersifat balas dendam/emosional/sewenang-wenang/tidak terkendali atau bersifat "extralegal execution". Artinya, disediakannya pidana mati dalam undang-undang dimkasudkan untuk memberikan saluran emosi/tuntutan masyarakat. Tidak tersedianya pidana mati dalam undang-undang bukan merupakan jaminan tidak adanya pidana mati dalam masyarakat. Oleh karena itu, untuk menghindari emosi balas dendam pribadi masyarakat yang tidak rasional, dipandang lebih bijaksana apabila pidana mati tetap tersedia dalam undang-undang;

b. Seandainya pidana mati tidak diterapkan terhadap delik korupsi, dikhawatirkan perkembangan korupsi tidak dapat dibatasi oleh karena korupsi tersebut digolongkan sebagai bentuk perbuatan yang keterlaluan, mencederai prinsip dasar bernegara, merusak tatanan masyarakat dan konstitusi, sehingga adalah wajar apabila dijatuhi pidana mati. ${ }^{28}$

c. Pidana mati merupakan alat penting untuk penerapan yang baik dari hukum pidana oleh karena kemanfaatannya sebagai alat penguasa agar norma hukum dipatuhi;

d. Pidana mati sangat dibutuhkan dalam era pembangunan terhadap mereka yang menghambat proses pembangunan. Korupsi dapat diartikan menghambat proses pembangunan oleh karena sifatnya yang merugikan perekonomian negara.

Berdasarkan hasil temuan penelitian diketahui bahwa kebijakan formulasi ancaman hukuman mati pada taraf implementasinya tidak satu pun Hakim yang menjatuhkan hukuman mati terhadap terdakwa kasus korupsi, hal ini disebabkan karena alasan kemanusiaan (hak asasi manusia) di samping itu lemahnya regulasi legislasi serta lemahnya pelaksanaan kebijakan (political action) pemerintah maupun aparat penegak hukum. ${ }^{29}$

Tampaknya hukuman mati sebagaimana yang dirumuskan dalam ketentuan Pasal 2 ayat (2) sulit untuk diterapkan, pasalnya Hakim selama ini hanya bertumpu peraturan perundang-undangan dan pada perspektif Hakim di dalam menjatuhkan keputusannya yang merupakan

26 Djoko Prakoso dan Nurwachid, Studi Tentang Pendapat-Pendapat Mengenai Efektivitas Pidana Mati Di Indonesia Dewasa Ini, Ghalia Indonesia, Jakarta, 1983, hlm. 97

27 Op.Cit, Dwi Lapriesta, hlm. 6.

28 SR Sianturi dan Mompang Panggabean, Hukum Penitensir di Indonesia, Alumni Ahaem Petahaem, Bandung, 1999, hlm.62

29 Ahmad Basuki, Pakta Integritas Di Tengah Suramnya Pemberantasan Tindak Pidana Korupsi Di Indonesia, Perspektif, Volume 15 No. 1, Januari 2010, hlm. 41-42 
hak preogatif yang tidak dapat diganggu gugat. Untuk itu, hal ini sangat disayangkan kelemahan formulasi pidana mati dalam ketentuan Pasal 2 Ayat (2) Undang-Undang No. 31 Tahun 1999 jo. Undang-Undang No. 20 Tahun 2001 tentang Pemberantasan Tindak Pidana Korupsi, tidak dilihat sebagai suatu persoalan yang seharusnya diperbaiki atau diamandemen oleh Undang-Undang itu sendiri. Akan tetapi justru yang dirubah atau diperbaiki dari Undang-Undang ini hanya redaksi penjelasan Pasal 2 Ayat (2). Sementara itu formulasi alasan yuridisnya terkait dengan recidive tidak mengalami perubahan. ${ }^{30}$

\section{Kendala dan Solusi Yang Dilakukan Dalam Kebijakan Formulasi Ancaman Pidana Mati Dalam Undang-Undang No. 31 Tahun 1999 jo. Undang-Undang No. 20 Tahun 2001 tentang Pemberantasan Tindak Pidana Korupsi}

Ditetapkannya pidana mati sebagai salah satu sarana di dalam penanggulangan kejahatan pada prinsipnya adalah suatu pilihan atas suatu kebijakan. Tentunya dalam menentukan kebijakan sering kali menuai reaksi dari berbagai kalangan baik yang setuju maupun tidak setuju, hal ini dapat dimaklumi mengingat sudut pandang seseorang yang berbeda dalam memahaminya. Namun yang terpenting dalam setiap kebijakan adalah sejauh mana kebijakan tersebut mampu memberi nilai kemanfaatan bagi masyarakat dan mampu menanggulangi kejahatan sesuai dengan tujuan perumusan kebijakan tersebut.

Beberapa kendala-kendala yang mempengaruhi dalam penerapan Undang-Undang Tindak Pidana Korupsi, sebagaimana yang diungkapkan Bambang Poernomo, yaitu : pertama, adanya perbedaan pandangan dalam mengevaluasi dan memberikan tindak lanjut terhadap hasil suatu pemeriksaan, aparat pengawas fungsional pada umumnya lebih menekankan kepada aspek-aspek managerial dan keperdataan, sedangkan aparat penegak hukum lebih menekankan pada aspek pidananya. Kedua, persepsi dan profesionalisme aparat penegak hukum dalam melaksanakan UU RI,No 3 Tahun 1971 jo.UU No 3 Tahun 1999, yang berpengaruh di dalam pelaksanaan di lapangan. Ketiga, kurang keterbukaan aparat pemerintah pada umumnya, bahkan terkadang bersikap menutup-nutupi, sehingga aparat hukum sulit untuk mendapatkan alat-alat bukti yang dibutuhkan sehingga akhirnya tercipta situasi yang kurang mendukung pengungkapanya dan mengakibatkan dianggap kurang cukup bukti atas tindak pidana tersebut. Keempat, Kondisi sosial politik daerah setempat yang kurang menguntungkan dalam penegakan terhadap kejahatan korupsi oleh aparat penegak hukum. ${ }^{31}$

30 Poster Sitorus, Rekonstruksi Ancaman Pidana Tindak Pidana Korupsipasal 2 Dengan Pasal 3 Undang-Undang Nomor 31 Tahun 1999 Jo. Undang-Undang Nomor 20 Tahun 2001 Tentang Pemberantasan Tindak Pidana Korupsi, Jurnal Mahasiswa Fakuyltas Hukum: Magister Ilmu Hukum dan Kenotariatan Universitas Brawijaya, Edisi Januari 2015, hlm. 9-10

31 Bambang Poernomo, Potensi Kejahatah Korupsi di Indonesia, Bina Aksara, Jakarta, 1983, hlm. 44. 
Melihat kendala-kendala dan atau kelemahan dalam kebijakan formulasi ancaman hukumam pidana mati dalam ketentuan UndangUndang No. 31 Tahun 1999 jo. Undang-Undang No. 20 Tahun 2001 tentang pemberantasan tindak pidana korupsi di atas, maka sebenarnya perlu adanya kebijakan integral dalam penanggulangannya, dalam arti bukan hanya diarahkan kepada praktis operasionalnya saja, melainkan langkah awal yang harus diterapkan adalah legislasi. ${ }^{32}$ Beberapa solusi yang dapat dilakukan terkait kendala-kendala kebijakan formulasi ancaman pidana mati dalam pemberantasan tindak pidana korupsi, yaitu pertama, pencabutan terhadap hak-hak tertentu terpidana misalnya hak untuk memilih dan dipilih dalam pemilihan yang diadakan berdasarkan aturan-aturan umum, hak untuk memangku jabatan publik atau jabatan tertentu, hak untuk bekerja pada perusahaan-perusahaan, hak untuk mendapatkan perizinan-perizinan tertentu yakni izin usaha, izin praktek seperti Dokter, Advokat, Notaris, hak menjalankan kekuasaan bapak/menjalankan perwalian atau pengampuan atas anak sendiri dan lain-lain. Pencabutan hak-hak tertentu tidak berarti hak-hak terpidana dapat dicabut. Pencabutan tersebut tidak meliputi pencabutan hak-hak kehidupan dan juga hak-hak sipil (perdata) dan hak ketatanegaraan. Dahulu dikenal pidana kematian perdata, yang dalam Undang-Undang Dasar Tahun 1950 dahulu tegas dilarang. ${ }^{33}$

Kedua, perampasan barang-barang tertentu misalnya barang milik terpidana atau orang lain yang seluruhnya atau sebagian besar diperoleh dari tindak pidana, barang yang ada hubungannya dengan terwujudnya tindak pidana, barang yang digunakan untuk mewujudkan atau mempersiapkan tindak pidana, barang yang dibuat atau diperuntukkan bagi terwujudnya tindak pidana. Ketiga, pemiskinan koruptor dengan cara mengganti uang denda. Keempat, keberanian pemerintah, lembaga legislator serta aparat hukum dalam melaksanakan kebijakan (political action) terkait menetapkan penjatuhan sanksi pidana mati terhadap para pelaku korupsi. ${ }^{34}$ Peran pemeritah dan lembaga legislator di nilai sangat urgen terutama dalam penerapan sanksi tersebut mengingat keduanya merupakan organisasi yang memiliki kekuasaan untuk membuat dan menerapkan hukum serta UndangUndang di wilayah tertentu. Dalam perspektif lain pemerintah juga mempunyai daya paksa terhadap masyarakat untuk melaksanakan

32 Ramdhan Dwi Saputro, Lucky Endrawati, Nurini Aprilianda, Reformulasi Wewenang Komisi Pemberantasan Korupsi Dalam Penuntutan Pada Tindak Pidana Pencucian Uang Yang Berasal Dari Tindak Pidana Korupsi, Jurnal Mahasiswa Fakultas Hukum: Sarjana IImu Hukum Universitas Brawijaya, September 2014, hlm 12-13

33 Shiddiqy, Rizky Aji, Membangun Zona Integritas Sebagai Upaya Pemberantasan Korupsi, Jurnal IImiah Mahasiswa FEB: Universitas Brawijaya, Volume 2 NO. 2, 2014, hlm. 8-10

34 Taufiq, Madiasa Ablisar, Sunarmi, Mahmud Mulyadi, Penerapan Undang-Undang No. 8 Tahun 2010 Tentang Pencegahan Dan Pemberantasan Tindak Pidana Pencucian Uang Dalam Perkara Tindak Pidana Korupsi Oleh Kejaksaan Tinggi Sumut, USU Law Journal, Volume 7 No.1, 2019, hlm. 138 
semua aturan hukum dengan memberikan sanksi bagi yang tidak mentaatinya. ${ }^{35}$

\section{PENUTUP}

Berdasarkan hasil pembahasan pada bab sebelumnya, maka dapat ditarik simpulan bahwa Pidana mati adalah pidana yang terberat. Karena pidana ini berupa pidana yang terberat, yang pelaksanaannya berupa penyerangan tehadap hak hidup bagi manusia yang sesungguhnya hak ini hanya berada ditangan Tuhan, maka tidak heran sejak dulu sampai sekarang menimbulkan pendapat pro dan kontra, bergantung dari kepentingan dan cara memandang pidana mati tu sendiri. Sedangkan tindak pidana korupsi adalah tingkah laku individu yang menggunakan wewenang dan jabatan guna mengeruk keuntungan pribadi, merugikan kepentingan umm dan negara. Kebijakan formulasi ancaman pidana mati dalam tindak pidana korupsi pada hakikatnya merupakan bentuk sanksi pidana maksimal khusus di mana pada taraf implementasinya sulit untuk diterapkan di Indonesia disebabkan perbedaan pendapat baik antara yang pro dan kontra dikalangan para sarjana hukum dan sudah barang tentu dengan mendasarkan pada alasan-alasan tertentu. Terhadap penjatuhan pidana mati kepada koruptor hanya dapat dilakukan apabila dalam keadaan tertentu.

\section{DAFTAR PUSTAKA}

\section{A. Buku :}

Andi Hamzah, 1994, Sistem Pidana dan Pemidanaan di Indonesia, Pradya Paramita, Jakarta;

Darwan Prinst, 2002, Pemberantasan Tindak Pidana Korupsi, Bandung;

Djoko Prakoso, 1988, Hukum Penitensir Di Indonesia, Armico, Bandung;

Jeremy Pope, 2003, Strategi Memberantas Korupsi : Elemen Sistem Integrasi Nasional, Edisi I, Yayasan Obor Indonesia, Jakarta;

Lembaga Administrasi Negara Republik Indonesia, 2009, Pemberatan Korupsi (Modul Pilot Project Pendidikan dan Pelatihan Pra Jabatan), Jakarta;

Muladi, 1992, Lembaga Pidana Bersyarat, Alumni, Bandung;

Martiman Prodjohamidjojo, 1995, Memahami Dasar-Dasar Hukum Pidana Indonesia, Pradnya Paramita, Jakarta;

SR Sianturi dan Mompang Panggabean, 1999, Hukum Penitensir di Indonesia, 1999, Alumni Ahaem Petahaem, Bandung;

Sutochid Kartanegara, 1999, Hukum Pidana Bagian Satu, Balai Lektur

35Diana Yusyanti, Strategi Pemberantasan Korupsi Melalui Pendekatan Politik Hukum, Penegakan Hukum Dan Budaya Hukum, E-Journal Widya Yustisia, Volume 1 No. 2, 2018, hlm. 95-96 
Mahasiswa, Jakarta;

Winastiti Yuliana Sekarpuri, 2009, Implementasi Purusan Pidana Mati Oleh Kejaksaan Negeri Surakarta Dalam Perkara Pembunuhan Berencana, Sebelas Maret, Surakarta;

Wahyudi, 2009, Kejahatan, Pengadilan dan Hukum Pidana, Mandar Mau, Bandung;

\section{B. Jurnal :}

A. Ahsin Thohari, (Bukan) Menggantang Asap Pemberantasan Korupsi Di Indonesia, Jurnal Legislasi Indonesia, Volume 8 No. 2, 2011;

AA Parimita, Gede Khrisna Putra, Edward Thomas Lamury, Wewenang Komisi Pemberantasan Korupsi Dalam Penyadapan Untuk Mengungkap Kasus Tindak Pidana Korupsi, Kertha Negara: Jurnal IImu Hukum, Volume 7 Nomor 8, 2019;

Ahmad Basuki, Pakta Integritas Di Tengah Suramnya Pemberantasan Tindak Pidana Korupsi Di Indonesia, Perspektif, Volume 15 No. 1, Januari 2010;

Diana Yusyanti, Strategi Pemberantasan Korupsi Melalui Pendekatan Politik Hukum, Penegakan Hukum Dan Budaya Hukum, E-Journal Widya Yustisia, Volume 1 No. 2, 2018;

Dwi Lapriesta R, Nyoman A. Martana, Analisis Terhadap Kebijakan Pemerintah Dalam Pemberantasan Korupsi Sebagai Upaya Menciptakan Pemerintahan Yang Bersih (Clean Governance), Jurnal Kertha Negara, Volume 4 No. 2, Februari 2016;

Krisnanda Etika Putri, Eko Soponyono, R.B. Sularto, Rekonstruksi Kebijakan Hukum Pidana Terhadap Eksekusi Pidana Mati, Diponegoro Law Journal, Volume 5 No. 3, 2016;

Mahardika, Firman Wijaya, Kajian Yuridis Fungsi Pencegahan Komisi Pemberantasan Korupsi Dalam Pemberantasan Tindak Pidana Korupsi Pengadaan Barang Dan Jasa Secara Elektronik Di Provinsi Dki Jakarta, Jurnal Hukum Adigama, Volume 1 No. 2, Januari 2018;

Moch Choirul Rizal, Kebijakan Hukum Tentang Bantuan Hukum Untuk Pemberantasan Korupsi Di Indonesia, Al-Jinayah: Jurnal Hukum Pidana Islam, Volume 4 No. 1, Juni 2018;

Mustaghfirin dan Irwanto Efendi, Tinjauan Yuridis Terhadap Implementasi Pidana Korupsi Dalam Upaya Mengembalikan Kerugian Keuangan Negara, Jurnal Pembaharuan Hukum, Volume 2 No. 1 2015;

Poster Sitorus, Rekonstruksi Ancaman Pidana Tindak Pidana Korupsipasal 2 Dengan Pasal 3 Undang-Undang Nomor 31 Tahun 1999 Jo. UndangUndang Nomor 20 Tahun 2001 Tentang Pemberantasan Tindak Pidana Korupsi, Jurnal Mahasiswa Fakuyltas Hukum: Magister IImu Hukum dan Kenotariatan Universitas Brawijaya, Edisi Januari 2015; 
Ramdhan Dwi Saputro, Lucky Endrawati, Nurini Aprilianda, Reformulasi Wewenang Komisi Pemberantasan Korupsi Dalam Penuntutan Pada Tindak Pidana Pencucian Uang Yang Berasal Dari Tindak Pidana Korupsi, Jurnal Mahasiswa Fakultas Hukum: Sarjana IImu Hukum Universitas Brawijaya, September, 2014;

Taufiq, Madiasa Ablisar, Sunarmi, Mahmud Mulyadi, Penerapan UndangUndang No. 8 Tahun 2010 Tentang Pencegahan Dan Pemberantasan Tindak Pidana Pencucian Uang Dalam Perkara Tindak Pidana Korupsi Oleh Kejaksaan Tinggi Sumut, USU Law Journal, Volume 7 No.1, 2019 